$$
\text { مدير المعهد : موث المصل واللقاح - مدرال درية شرفباسية }
$$

$$
\text { دراسة حيوية ميكروبي الكلوستريديم شوفياي، }
$$

$$
\text { اقبال فر اج ، عبد السلام زكي ، رقية عثمان ، محمد عبيد }
$$

أضيفت كمية معلومة من الخلايا الخضرية و الحويصلات لكل من ميكروبي كلوستريديم

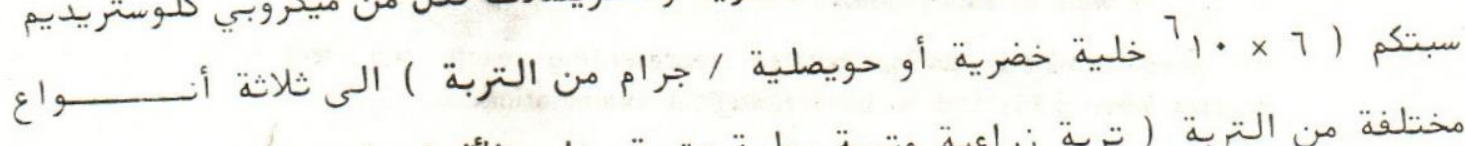

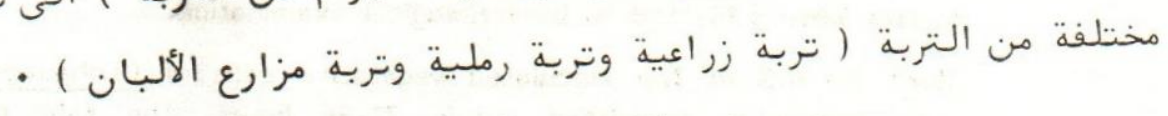

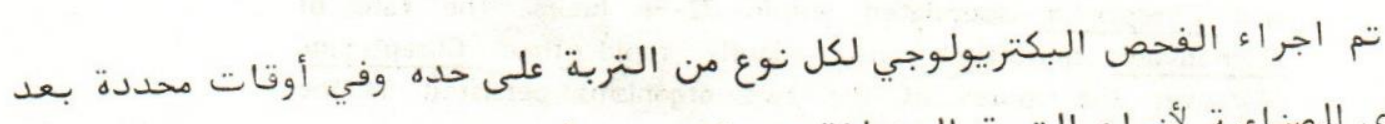

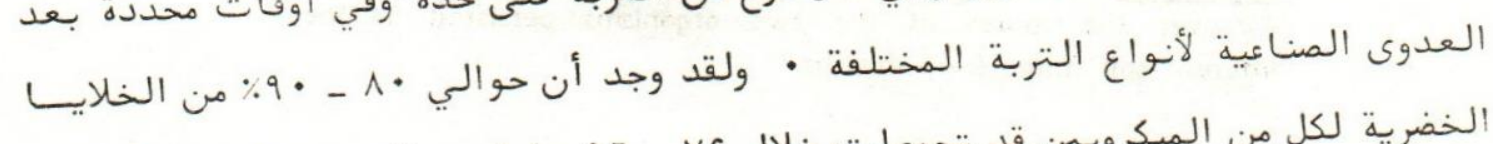

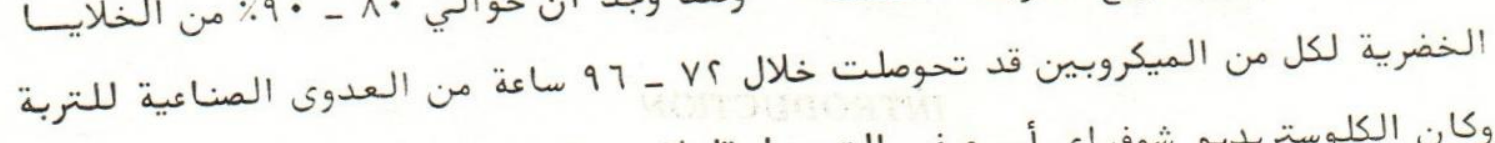

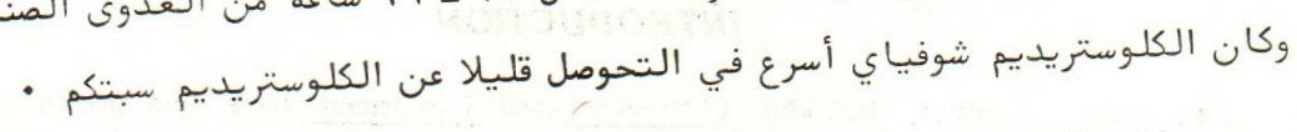

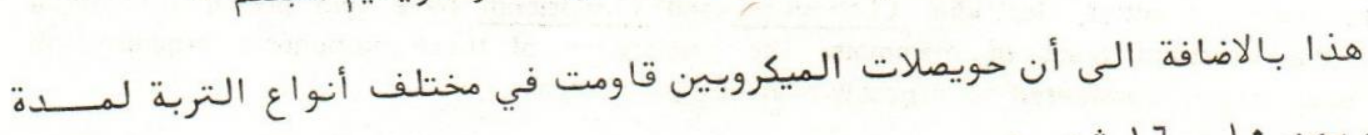
•تتراوح بين •1 - 17 شهر 
Vet. Serum and Vaccine Research Institute,

Head of Dept. prof. Dr. Doreia Sharaf.

\title{
SURVIVAL OF CLOSTRIDIUM CHAUVOEI AND CLOSTRIDIUM SEPTICUM IN ARTIFICIALLY INFECTED SOIL \\ (With 2 Tabies)
}

\author{
By \\ IKBAL FARRAG; A.Z. HUSSEIN; ROUKAYA OSSMAN \\ and M.H. EBEID* \\ (Received at $21 / 12 / 1987$ )
}

\begin{abstract}
SUMMARY
A known viable population of the washed irioculum of either Cl.chauvoei or Cl.septicum $\left(6 \times 10^{6}\right.$ spores or vegetative cells $/ \mathrm{gm}$ soil) was added to three types of soil (dairy farm soil, cultivated soil as well as sandy soil).

At predetermined times, bottles representing each soil and control were subjected to bacteriological examination.

About $80-90 \%$ of the inoculated vegetative cells of Cl.chauvoei and Cl.septicum sporulated within 72-96 hours. The rate of Cl.chauvoei sporulation was slightly rapid than Cl.septicum. Moreover the spores of the two organisms persisted in the different soil from 10-16 months.
\end{abstract}

\section{INTRODUCTION}

Like many of other clostridia, Cl.chauvoei and Cl.septicum have two principal habitats, soil and the intestinal tract of mammals. The persistence of these pathogenic organisms in soil has been largely considered as a problem in disease control.

MINETT and DHANDA (1941) found that Cl.chauvoei was not able to grow in soil when artificially inoculated unless the soil contained large amounits of organic matter. SHALKO and KORNILOVA (1955) were able to isolate Cl.chauvoei after 5 years in soil artificially infected. KOVALENKO (1956) found that in loamy soil Cl.chauvoei remaired alive for 13 months. POPESCU (1970) worked on the effect of some wild and cultivated plants on the persistence of Cl.chauvoei spores in soil, and found that it survived for 2-6 years according to the plant used. FARRAG (1972) isolated Cl.chauvoei from farm soil during an outbreak of blackleg in $40 \%$ of the samples examined and ir. $2.7 \%$ from those with two years previous history of the disease, while soil of non infected farms were free from the organism.

GARCIA and MCKAY (1969) inoculated Cl.septicum into soil treated by different ways and reported that vegetative forms persisted in both sterile arid unsterile soil for up to 30 days in incubated samples, and that glucose, peptone and marnose enhariced the growth and metabolic activity of the organism.

GARCIA and MCKAY (1970) considered Cl.septicum and Cl.chauvoei as pathogenic bacteria that could grow in soil. SMITH and HOLDMAN (1968) reported that Cl.septicum had been

* Fac. of Vet. Med., Bariha University. 
IKBAI. FARRAG, et al.

found in soil from all parts of the world, being present in greatest numbers in relatively fertile loam but being found even in saridy soil. POL NILKOU (1982) was able to isolate Cl.septicum deposited at depth of $5-10 \mathrm{~cm}$ in experimentally infected soil for 180 days but not after 12 months.

The aim of this work is to study the behaviour of $\mathrm{Cl}$.septicum and Cl.chauvoei under different circumstances such as the effect of moisture, $\mathrm{pH}$ value and organic matter in different types of Egyptian soil.

\section{MATERIAL and METHODS}

\section{Soil:}

Three types of soil were used in this study. Soil samples were obtained from a dairy farm, cultivated soil and sandy soil located at Giza Governorate. The samples contained organic matter $31 \%, 7 \%$ and $6 \% \mathrm{pH}$ values were $7.5,6$ and 6 and moisture $22 \%$, $16 \%$ and $3 \%$ respectively. The soil were dispensed in screw capped bottles each containing 25 grams of soil. These were sterilized by autoclaving for 30 minutes and rept at room temperature ready for use.

\section{Vegetative cell suspension:}

A pure 24 hours thioglycolate broth cultures of $\mathrm{Cl}$.chauvoei and Cl.septicum were prepared. The cells were harvested by centrifugation, washed twice with saline and then resuspended ir saline. The percentage of vegetative cells was $100 \%$ when tested microscopically just before soil irifection.

\section{Spore suspension:}

It was prepared according to COOPER, et al. (1960). The suspension was heated at $80^{\circ} \mathrm{C}$ for 15 minutes to kill any vegetative forms.

\section{Soil treatment:}

A known viable population of the washed inoculum of each organism $\left(6 \times 10^{6}\right.$ spores or vegetative cells $/ \mathrm{gm}$ ) was added to the bottles of sterilized soil. A set of un irioculated soil was left as control.

At predetermined times, bottles representing each soil and a control were subjected to bacteriological examination. Ter, fold dilutions were prepared from each bottle under test. Each soil dilution was shaken thoroughly befoie samples were withdrawn. Plating was done by spieading $0.1 \mathrm{ml}$ portion of appropriate dilution on blood agar. Stiff blood agar plates were used for Cl.septicum ( $5 \%$ agar). Colonies were counted after 48 hours anaerobic incubatior. The resulting counits correspond to the total viable clostridia (vegetative and spores) present in soil at the time of sampling. The proportion of spores in the total population was ascertained by counts made after heat treatirig the soil dilutions at $80^{\circ} \mathrm{C}$ for 10 mirutes before plating. The heating techrique was orily dore in soil dilutions infected with the vegetative cells to detect the percentage of sporulations at different times.

\section{RESULTS}

The rate of $\mathrm{Cl}$.chauvoei and $\mathrm{Cl}$ septicum snorulation in soils infected with vegetative cells:

Total viable counts of soil sampies infected with vegetative organisms were made at 24. 48. 72 and 96 hours after soil infection. During this period the total viable counit of both

Assiut Vet.Med.J. Vol. 20, No. 40, 1988. 


\section{CLOSTRIDIUM CHAUVOEI}

organisms was approximately the same as the original inoculum. The proportion of spores to the total population increased rapidly in all the types of soil and was more rapid in sandy soil than cultivated soil than dairy soil. The rate of Cl.chauvoei sporulation was slightly rapid than Cl.septicum.

The results are illustrated in Table (1).

\section{Survival of $\mathrm{Cl}$.chauvoei and $\mathrm{Cl}$ septicum spores in different types of soil:}

Total viable counts of soil samples infected with spores of Cl.chauvoei and Cl.septicum were made every two months after soil infection.

Cl.chauvoei decreased slightly at 2 months in the dairy farm soil. At 4 months the number decreased markedly until disappeared after 10 months. In cultivated and sandy soil, the spores started to decrease at 6 months and disappeared after 12 and 14 months respectively.

Cl.septicum spores remained approximately unchanged in sandy and cultivated soil for 6 months after which it declined to disappear completely at 16 month in cultivated soil while still persisted in small number in sandy soil. The number of spores in dairy farm soil started to decrease after 4 months until it disappeared after 12 months.

Results are illustrated in Table (2).

\section{DISCUSSION}

Epidemiological investigation have shown that the excretion of Clostridia by animals leads to contamination of the environment. These araerobes are believed to occur as spore forms and could cause diseases under appropriate conditions. Little is known, however, about which soil conditions favour the predominance of either vegetative cells or spores. The preceding results give some clarification, on the survival and sporulation rate of Cl.chauvoei and Cl.septicum in certain soils. Table (1) indicates that vegetative cells when inoculated into sterile soil sporulated rapidly arid in 96 hours most of the cells of both organisms were in spore form. This observation does not agree with GARCIA arid McKAY (1969) who suggested that Cl.septicum could multiply and survive in the vegetative form as it did not immediately sporulate wher, they inoculated it into the soil. The difference between our results and these authors may be due to that they added to their soil readily utilizable organic matter (glucose and manure) and incubated it at anaerobic condition which tended to delay the rate of sporulation.

Under farming conditions where turnover of readily available oraganic material like manure is frequent, the increase of the clostridial population might be maintained for a longer period.

There is a great discrepancy in the literature about the survival period of Cl.chauvoei and Cl.septicum spores. Our results (Table 2) indicate that Cl.septicum spores were more resistant than Cl.chauvoei in the three types of soil tested, but the unexpected results were that the spores of both organisms survived for longer periods in sandy soil than the cultivated and dairy farm soil. Also it was astonishing that the spores of both organisms particularly that of Cl.chauvosi did not persist for long time ir dairy farm soil.

It may be suggested that this was likely due to some proliferation of the spores to the vegetative forms (heat sensitive) in the dairy farm soil according to the presence of suitable $\mathrm{pH}$ (7.5), higher percent of orgaric matter and humidity.

Assiut Vet.Med.J. Vol. 20, No. 40, 1988 
IKBAL FARRAG, et al.

However, it could be concluded that the behaviour of clostridia under the condition of our investigation may be different than the natural enviromental conditions which is usually affected by different seasons, sun light, dryness and other factors.

\section{REFRRENCLS}

Cooper, M.S.i Marinie, F.V. and Personeus, G.R. (1960): Further studies in Cl.chauvoei infections and immunity in laboratory animals. Cornell Vet., 50, 301.

Farrag Ikbal (1972): Studies on blackleg among bovines in Egypt. M.Sc. Thesis, Fac. of Vet. Med. Cairo Unov.

Garcia, M.M. and McKay, K.A. (1969): On the growth and survival of Cl.septicum in soil. J. Appl. Bact. 32, 362-370.

Garcia, M.M. and McKay, K.A. (1970): Microorganisms in soil: An old problem in a new prespective. Cari J. Comp. Med. 34, 105.

Kovalenko, Y.R. (1956): Survival and vegetative growth of Cl.chauvoei in soil. Trud. Gasud. Nauchno. Kontrol Inst. Po. Vet. preparatum 6, 197.

Miriett, F.C. and Dhanda, M.R. (1941): Multiplication of B.anthracis and Cl.chauvoei in soil and water. Indian J. Vet. Sci. 11, 308.

Popescu, F.S. (1970): Effect of some wild and cultivated plants on the persistence of $\mathrm{Cl}$. chauvoei spores in soil. Arch. Vet. 7, 223.

Pol Nilkov, D.G. (1982): Persistence of pathogenic Clostridia in soil. Frunz, Kirgizskaya SSR, USSR, Isdatelstva "Glim" 87-91.

Shalko, P.D. arid Konilova, A.L. (1955): Some data on the survival of Cl.chauvoei spores in the soil. Veteririary, Moscow, 32, 76.

Smith, L.D.S. and Holdmar, Lillian (1968): The pathogenic anaerobic bacteria. Charles Thomas Publisher, U.S.A.

Table (1)

The percentage of spores to the total viable Clostridia in soils infected with vegetative cells

\begin{tabular}{ccccccc}
\hline \multirow{2}{*}{$\begin{array}{c}\text { Hours after } \\
\text { infection }\end{array}$} & \multicolumn{2}{c}{ Dairy farm soil } & \multicolumn{2}{c}{ Cultivated soil } & \multicolumn{2}{c}{ Sandy soil } \\
\cline { 2 - 6 } & Cl.ch. & Cl.sept. & Cl.ch. & Cl.sept. & Cl.ch. & Cl.sept. \\
\hline \multirow{2}{*}{24} & $10 \%$ & $5 \%$ & $10 \%$ & $10 \%$ & & \\
48 & $20 \%$ & $15 \%$ & $20 \%$ & $20 \%$ & $35 \%$ & $30 \%$ \\
72 & $60 \%$ & $50 \%$ & $70 \%$ & $60 \%$ & $80 \%$ & $75 \%$ \\
96 & $80 \%$ & $80 \%$ & $85 \%$ & $80 \%$ & $90 \%$ & $85 \%$ \\
\hline
\end{tabular}

Cl.ch. $=$ Cl.chauvoei

Cl.sept. = Cl.septicum 


\section{CLOSTRIDIUM CHAUVOEI}

\section{Table (2)}

Survival period of Cl.chauvoei and Clsepticum spores in different types of soil

\begin{tabular}{|c|c|c|c|c|c|c|}
\hline \multirow{2}{*}{$\begin{array}{l}\text { Period after } \\
\text { incubation }\end{array}$} & \multicolumn{2}{|c|}{ Dairy farm soil } & \multicolumn{2}{|c|}{ Cultivated soil } & \multicolumn{2}{|c|}{ Sandy soil } \\
\hline & Cl.ch. & Cl.sept. & Cl.ch. & Cl.sept. & Cl.ch. & Cl.sept. \\
\hline 2 months & $5.5 \times 10^{6}$ & $6 \times 10^{6}$ & $6 \times 10^{6}$ & $6 \times 10^{6}$ & $6 \times 10^{6}$ & $6 \times 10^{6}$ \\
\hline 4 months & $3.0 \times 10_{5}^{6}$ & $6 \times 10^{6}$ & $6 \times 10^{6}$ & $6 \times 10^{6}$ & $6 \times 10^{6}$ & $6 \times 10^{6}$ \\
\hline 6 moriths & $2.0 \times 10^{3}$ & $4 \times 10_{5}^{6}$ & $5 \times 10^{6}$ & $6 \times 10_{5}^{6}$ & $5 \times 10^{6}$ & $6 \times 10^{6}$ \\
\hline 8 moriths & $1.0 \times 10^{4}$ & $3 \times 10^{3}$ & $4 \times 10^{-}$ & $6 \times 10^{5}$ & $4 \times 10^{6}$ & $5 \times 10^{6}$ \\
\hline 10 months & $2.0 \times 10^{3}$ & $1 \times 10^{4}$ & $3 \times 10$ & $5 \times 10^{3}$ & $6 \times 10_{5}^{5}$ & $4 \times 10_{5}^{5}$ \\
\hline 12 moniths & - & $2 \times 10^{2}$ & $1 \times 10^{3}$ & $4 \times 10^{4}$ & $3 \times 10^{5}$ & $4 \times 10^{5}$ \\
\hline 14 months & - & - & - & $2 \times 10^{2}$ & $2 \times 10^{3}$ & $3 \times 10^{4}$ \\
\hline 16 months & - & - & - & - & - & $2 \times 10^{2}$ \\
\hline
\end{tabular}

